\title{
Have the Private Benefits in Italian Firms Decreased?
}

\author{
Carmelo Intrisano \\ University of Cassino, Cassino, Italy
}

\begin{abstract}
The topic of the paper is the estimate of the benefit of control, according to the Barclay and Holderness method. The reference system of this research is Italy, given that the empirical evidence of the past which had underlined private benefits particularly high among Italian companies and the reference period is 1999-2007. The idea of this research is to demonstrate that, since the Legislative Decree No. 58 of February 24, 1998 (Consolidated Law on Finance, henceforth Consolidated Law), which has significantly changed the protection of minority shareholders, in Italian, the intensity of private benefits has on average declined sharply. To this end, considering the results of the empirical researches on periods pre-1998 and at the turn of the Consolidated Law, the paper provides evidence that the improvement of minority shareholder protection already shown by these researches is further accentuated over the years, because of the effects that the new regulatory framework has produced. In fact, the basic assumption is that the important laws, as Consolidate Law, require several years to produce the desired results in full. This idea is supported by the findings of research that show an average percentage of private benefits dropped to five percent of the capital. Hence, the investigation is extended to the demonstration of comparability of this estimation with other estimations quoted in literature, verifying the statistical significance of the correlations between the measures estimated and the variables considered as determinants in much of the literature.
\end{abstract}

Keywords: private benefits of control, amenities, block premium, voting rights, insider shareholders, outside shareholders

\section{Introduction}

The controlling shareholder may take advantage of some benefits, known as private benefits since they are exclusively enjoyed and not shared with the other shareholders. This leads to a conflict of interest between inside shareholders and outside shareholders.

This phenomenon has been particularly intense in Italy, because there were the laws insufficiently aimed at protecting minority shareholders, the presence of many large shareholders, and the recurrent use of mechanisms to separate the ownership by the control. Starting 2008, the phenomenon became less intense, probably as result of changes in the law environment. The regulation has been enriched and strengthened by laws that protect investors, regulate the financial markets, strengthen the internal mechanisms of governance, ensure disclosure of corporate operations, and limit the opportunistic behaviors of the controlling shareholders.

Carmelo Intrisano, Professor, Department of Economy and Jurisprudence, University of Cassino.

Correspondence concerning this article should be addressed to Carmelo Intrisano, Sant’ Angelo Road, Cassino, Italy. E-mail: c.intrisano@eco.unicas.it. 
Moreover, in recent years the use of non-voting shares has been greatly reduced, so that the estimation methods based on the price differential between voting shares and non-voting shares are poorly effective to quantify the intensity of the private benefits phenomenon.

The present empirical work is developed on this basis, giving an estimate of private benefits in the new law framework. In the light of this, the paper is organized as follow. Section two reviews main references about the topic. Section three focuses the methodology. Section four shows the results. Section five outlines the conclusions.

\section{Literature}

Much attention was placed by scholars in the field of corporate governance on the private benefits of control, because of their ability to influence corporate performance and the protection of outside shareholders. Then, considered the various ways in which the private benefits may materialize, in literature, there are several definitions, each of which highlights a certain characteristic. In particular, Ehrhardt and Nowak (2003) schematized the private benefits of control in a matrix that considered their transferability and their nature, as Table 1 shows.

Table 1

Type of Benefits of Control

\begin{tabular}{|l|l|l|l|}
\hline & Pecuniary (Tunneling) & Non-pecuniary \\
\hline \multirow{5}{*}{ Trasferability } & Self-Dealing & Amenities \\
\cline { 3 - 4 } & $\begin{array}{l}\text { Excessive compensation; } \\
\text { Diversion of resources; } \\
\text { Asset transfers at arbitrary prices; } \\
\text { Cheap loans and guarantees }\end{array}$ & $\begin{array}{l}\text { Winning the world series; } \\
\text { Influencing public opinion; } \\
\text { Owning a luxury brand; } \\
\text { Physical appointments }\end{array}$ \\
\cline { 2 - 4 } & Low & $\begin{array}{l}\text { Dilution } \\
\text { Insider trading; } \\
\text { Creeping acquisitions; } \\
\text { Freeze-out and squeeze-out; } \\
\text { Issuance of shares at dilutive prices }\end{array}$ & $\begin{array}{l}\text { Social prestige; } \\
\text { Family tradition; } \\
\text { Promotion of relatives; } \\
\text { Personal traditions }\end{array}$ \\
\hline
\end{tabular}

Note. Source: Ehrhardt and Nowak, 2003.

In general, the private benefits of control include everything that an insider shareholder takes from control without sharing with other shareholders (Coffee, 1991; Coates, 2003).

Private benefits derive from the transfer of control in which the buyer takes significant synergies from the transaction (Grossman \& Hart, 1988). Other benefits arise when there are transfers of corporate assets in subsidiaries at unjustified prices or investments in associated companies at inflated prices (Modigliani \& Perotti, 2000).

The private benefits is often closely linked to self-dealing transactions made by the controlling shareholder. In general, self-dealing activities are realized when the controlling shareholder uses his/her power over the management drawing benefit at the expense of other shareholders. Self-dealing transactions are those between the company and its director, or between the company and a third party in respect of which the majority shareholder nurtures an interest.

Obviously, these transactions are detrimental to the minority shareholders only when the result is less beneficial to company than what could be achieved if the transaction had been concluded by a manager who is not 
in a conflict of interest (Enriques, 2000). A form of self-dealing and therefore private benefits, is where the majority shareholder, recompenses himself/herself a salary well above his/her service rendered, and in this way worsens the profit margins of the firm, and therefore, the profits which the minority shareholders are entitled in proportion to their holdings (Hanouna, Sarin, \& Shapiro, 2001).

Other forms of benefits are described with reference to the tunneling carried out through self-dealing transactions which include illegal activities such as theft or fraud, and apparently legal activities such as the sale or purchase of products at different prices than market ones, the guarantees given by the firm on loans obtained by the majority shareholder, and more generally, the investment management designed for personal interest (Jonson et al., 2000).

A form of pecuniary private benefits is represented by the higher price that the controlling shareholder receives in the event of disposal of his/her shares. In fact, the price of the block discounts the cash flows associated with private benefits (Gilson \& Gordon, 2003).

Private benefits are also non-pecuniary. Bebchuk (1994) mentioned an example of non-pecuniary benefits the increase of synergies or market power that the controlling shareholder may acquire entering in other business.

So it is a private benefit that the value embedded in corporate informations, which can be accessed by the majority shareholders, involved in the management. Some of these informations are directly related to the activities of the firm, while others reflect business opportunities. The controlling shareholder can easily exploit these opportunities, for example, through one of its subsidiaries excluding the minority shareholders. The net present value of these opportunities is the measure of the private benefits of control (Dyck \& Zingales, 2004).

Particular attention is given by Demsetz and Lehn (1985) for non-pecuniary benefits, also referred to as amenity potential. These benefits were closely related to the management of activities such as sports clubs in which the benefits come from winning a competition or the media in which the benefits are associated with the possibility to influence the information.

As regard to the methodology for estimating private benefits, in literature two different approaches have emerged. The first method is based on the voting premium that represents the price differential between voting shares and non-voting shares (Levy, 1983; Lease, McConnell, \& Mikkelsen, 1983; Zingales, 1994). A second method is instead based on the measurement of control premium, i.e., the difference between the price paid for the control block and the market price (Barclay \& Holderness, 1989; Dick \& Zingales, 2004).

The literature is also full of empirical evidence. In this regard, the researchers agree that the benefits grow with the size of the investment, the benefits also depend on the ownership's structure and change significantly between countries because of different corporate governance and legal systems (Nenova, 2003). In addition, the researchers agree that the private benefits are influenced by the specific characteristics of the firm, such as sector, size, level of debt, risk, performance, and statutory provisions.

In particular, with regard to the empirical evidence extended to non-Italian firms and based on the method of the price differential between voting shares and non-voting shares, the most interesting reaserches are as follows. Lease et al. (1983) studied the stock prices of 30 U.S. dual class companies in the period 1940-1978 and estimated an average voting premium around 5.4 percent. Megginson (1990) focused on the UK market for the period 1955-1982 and estimated a voting premium of 13.3 percent. 
Instead, the empirical evidence based on non-Italian premium control blocks, the most known researches are as follows: Barclay and Holderness (1989) analyzed 63 transactions of blocks of shares in the U.S. market in the period 1978-1982 and showed an average premium of 20.4 percent. Dick and Zingales (2004) following the approach of Barclay and Holderness (1989), analyzed 412 transactions in 39 different countries over the period 1990-2000 and found that the premium of the control range between the extreme highest of countries that had a premium more than 25 percent, such as Argentina, Austria, Colombia, Czech Republic, Israel, Italy, Turkey, Venezuela, and Brazil, and the extreme lower countries that have a premium of around three percent, such as Australia, Canada, Finland, France, Hong Kong, Japan, Netherlands, New Zealand, Norway, Singapore, South Africa, Taiwan, UK, and U.S.. Gregoric and Vespro (1993) analyzed transactions in Slovenia and estimated an average premium of 46.7 percent and a standard premium equal to 5.7 percent of the capital transferred. Trojanowski (2002) analyzed a sample of transactions in Poland and estimated a premium equal to 9.1 percent before the transaction and 6.8 percent after the transaction.

Barak, Cohen, and Lauterbach (2007) analyzed a sample of transactions in Israel and estimated a premium of around 30 percent. Nenova use a particular method to estimate the phenomenon on a sample of 661 companies from 30 different countries. The method, in fact, is based on the approach of the vote value which is the lower limit of private benefits. This premium is determined by Nenova in values higher than 20 percent of the market capitalization of the company for countries like Brazil, Chile, France, Italy, Mexico, and South Korea, in values between 10 and 15 percent for the Germanic countries, such as Switzerland and Germany and in values close to zero for the Anglo-Saxon countries and Scandinavia.

With regard to the empirical evidence concerning exclusively Italy, it notes the following reasearches. Caprio, Floreani, and Radaelli (1994) analyzed a sample of 189 transfers in Italy during the period 1970-1991, quantified the surcharge paid on a subsample of 33 transfers and estimated this surcharge which was on average equal to 34.4 percent of the price prior the transaction and equal to 48.9 of the price following the transaction. Zingales (1994) analyzed the prices of the voting shares and non-voting shares for the period 1970-1991 and came to the conclusion of a price differential equal to 82 percent compared with the average in other countries ranges between 10 and 20 percent.

Nicodano and Sembenelli (2000) analyzed the transfer of control considering a sample of 64 manufacturing companies selected in the period 1987-1992 and came to the estimation of a transfer price on average more than 27.4 percent of the post transaction. Linciano (2002) analyzed a sample of 80 companies between 1989 and 2000 and estimated a reduction in the voting premium between 5.4 and 6.5 percent which, in terms of benefits, corresponds to an average reduction of between 21 percent and 25 percent, as a result of the new Law. Massari, Monge, and Zanetti (2004) analyzed a sample of 27 transactions during the period 1993-2003 and estimated an average premium equal to 21.8 percent of the market price following the transaction, and a value of private benefits that varies between 12 and 14 percent.

\section{Methodology}

The sample is built through the analysis of shareholders of Italian listed companies on the Italian Stock Exchange in 1999-2007. The period chosen is a uniform period from a regulatory perspective because:

- In 1998, the introduction of the Consolidated Law has changed the regulatory framework in in Italy for the 
protection of minority shareholders and thus had significant effect on the value of private benefits;

- In the years after 2007, further legal provisions have been issued, although which was lesser importance than the Consolidated Law, led to changes in the regulatory framework.

The shareholders data are acquired from the Consob archive. The research excludes banks, insurance companies, asset management companies, and financial holding companies, as their book values are not comparable with those of other companies and it also excludes new entrants and companies no longer listed, because they have incomplete informations than those required by the empirical evidence. So, companies that have undergone a change in ownership which are carefully evaluated in order to understand how and why the transfer. The merger and acquisition database by the Thomson Financial and the on-line Milano Finanza and the Il Sole 24 Ore are used. On this basis, the research selects the following kinds of transactions of blocks:

- transactions taking place between the largest shareholder and a new shareholder, in which case the new shareholder has taken over the position of the largest shareholder, while the latter is out of the corporate structure of control;

- transactions taking place between the largest shareholder and a minority shareholder, as a result of which the largest shareholder has significantly reduced its ownership maintaining the control, while the minority shareholder has increased its stake, which becomes close to that of majority shareholder;

- transactions that modify the structure of the shareolders' agreement, through which it has control of the company;

- transactions with which the buyer of the block enters in the control group through a shareholders' agreement or the board of directors or appoint at least one director.

In line with the methodology of Dick and Zingales (2004), the papers consider only the transactions of blocks which transfer a percentage of capital less than 30 percent, excluding those that are part of a public offering. In fact, the Italian legislation for the protection of minorities, requires equal treatment of all shareholders and therefore limit the private benefits of control. The paper also excludes the transfers that bring a pubblic offering because the trading of the block may be influenced by the purchasing of the acquisition of the remaining shares (Dick \& Zingales, 2004) and the market price, anticipating the next Opa, tends to the price of the transfer (Linciano, 2002).

This research also excludes:

- transactions related to the spin-off, recapitalization, and capital increase;

- transactions, which news do not include all the details about the terms of the transaction, the buyer and the seller, the block size, and the type of payment;

- transactions not settled entirely in cash, but including payments in stocks or bonds, because of the difficulty in assessing the exact value of the shares;

- share transfers occurred between a company and its subsidiary or between subsidiaries of the same company, as the selling price can not be considered informative.

On this basis, the panel is composed of 21 transactions. The model used for estimating the value of the control is suggested by Barclay and Holderness (1989). The postulated is that the price paid for a significant fraction of the voting rights reflects the possibility that the parties involved in the transaction get benefits of control. 
If the buyer and the seller are able to anticipate the market's response to the operation, the sale price of the block incorporates expectations of the market price after the transaction. Consequently, the post-transaction price includes both the public benefits and the private benefits of control, so the block premium is equal to:

$$
\text { PREMIUM }_{t}=\frac{P_{i}-P_{i, t+1}}{P_{i, t+1}}
$$

where:

$P_{i}$ is the price per share paid for the block;

$P_{i, t+1}$ is the market price one day after the transaction.

However, if the buyer and the seller are not able to predict market trends, the transfer price will refer to the pre-transaction price and the premium is equal to:

$$
\text { PREMIUM }_{t}=\frac{P_{i}-P_{i, t-1}}{P_{i, t-1}}
$$

where $P_{i, t-1}$ is the market price a day before the transaction.

It follows that the standard of control premium, i.e., the premium expressed as a percentage of the share capital is:

$$
\text { STANDARD PREMIUM } M_{t}=\frac{P_{i}-P_{i, t-1}}{P_{i, t-1}} \times \alpha
$$

where $\alpha$ is the controlling share held by the shareholder.

In this research, the above formulas have been applied to considering separately the prices of the two ( $t-1$, $t-2)$ days $(t-1, t-2)$ prior to the transaction and the next two days $(t-1, t-2)$.

To identify the determinants of the premium, this research proceeds with the multiple regression analysis, in which the dependent variable is obviously represented by the premium. In particular, the determinants considered as explanatory variables of block premium are represented by variables representative of the structure of the property, as the size of the investment, the identity of the buyer, the degree of separation between ownership and control, the voting power in the control group, and variables representative of company characteristics, such as company size, performance, and debt. These determinants are the variables most used in the previous researches on private benefits, so that it can compare the results of the research with the results of previous estimations that are present in literature.

The voting power of the control group is relevant for the premium, considered that the block assumes a different value depending on the probability that the buyer can acquire the block of control. This probability, for example, is the greatest one where the rest of the shares are dispersed with respect to the case where instead there is another shareholder with a substantial interest. Given this, the voting power is measured by Shapley ratio, equal to the probability that the investor is pivotal in a random coalition. Consequently, it depends on the size of ownership and on the dispersion of all other investments. In estimating the value of Shapley, special attention is given to the presence of shareholders' agreements which binding the participants in the shareholders' vote and in the selection of members of the board of directors. In these cases, the Shapley value of the buyer is calculated by considering the total ownership of shareholders that signed the agreement but not the ownership of the individual shareholder.

With regard to the separation of ownership and control, this variable was considered potentially 
determinable for the benefits of control, considering that when ownership and control are separated, the majority of shareholders have an incentive to extract private benefits. The high lever of control over the capital, implemented by means of pyramids, promotes the extraction of benefits, as corporate control is in the hands of a shareholder who owns only a small fraction of cash flow rights. Also the shares with limited voting rights favor the separation of ownership and control.

In light of this, the analysis was carried out with two dummy variables: the variable pyramids, with value 1 when the buyer obtains control through a corporate chain and otherwise 0 , the dual class variable with value 1 if the target company has issued shares with limited voting rights.

The taking of variables related to the identity of the buyer is based on the assumption that the characteristics of shareholders affect the ability and willingness to extract private benefits. Demsetz and Lehn (1985) observed that the probability of extraction of private benefits is greatest when there are individuals that have the control, considered the greatest value that is attributed by individuals to the benefits, including those non-pecuniary. For this variable, the investigation considers the following two dummy variables: a company takes the value 1 if the buyer is a company, otherwise 0 ; individual takes the value 1 if the purchaser is an individual, otherwise 0 .

\section{Results}

In the sample 15 transaction of blocks have a positive premium and six a negative premium. Table 2 in the first column shows a substantial homogeneity of values in the days considered for the estimation of block premium. The second column shows the block average premium for all 21 observations which is around eight percent compared with the market price after-sales. The third column indicates the block premium of the transactions that have a negative premium. The existence of a negative premium is also in line with other empirical evidence, and, in particular, the investigation by Barclay and Holderness (1989) showed that it represented the research of reference for all the empirical evidence based on block premium. In fact, Barclay and Holderness (1989) noted that about 20 percent of the sample transactions occurred at a discount compared with the price after the transaction. In general, the transactions with premium negative are characterized by a lower price of the block at the market price. This difference corresponds to the costs that the buyer of the block will support when he/she becomes to be part of the controlling shareholders, such as monitoring costs and costs for legal expenses related to conflicts with minority shareholders. In the sample of the paper, the six transactions with negative premium have an average discount around three percent. The fourth column refers only to 15 transactions for which the buyer has paid a higher price than the market price. This is the reason why the premium is called block modified premium to distinguish it from premium calculated on all 21 transactions. As it notes, the purchasing of the control comes at a price of 17 percent higher on average than the market price. The last column, that indicates the standard premium, shows an average amount of private benefits around five percent of the capital.

With reference to the identification of determinants, the variables have the values of Table 3.

Then it proceeds by regressing the estimates of the block premium on the explanatory variables. The variables OWNERSHIP and DEBT are included in the model as a logarithmic transformation in order to search for statistically significant correlations between the variables. 
The model is the following:

$$
\begin{gathered}
\text { Block Premium }=\alpha_{0}+\alpha_{1}(\text { OWNERSHIP })+\alpha_{2}(\text { COMPANY })+\alpha_{3}(\text { INDIVIDUAL })+\alpha_{4}(\text { POWER })+\alpha_{5}(\text { PYRAMID })+ \\
\alpha_{6}(\text { DUAL CLASS })+\alpha_{7} \operatorname{Ln}(\text { SIZE })+\alpha_{8}(\text { DEBT })+\alpha_{9}(\text { PERFORMANCE })
\end{gathered}
$$

The estimate of the model leads to coefficients significantly no different from zero, as Table 4 shows.

Table 2

Block Premium Average

\begin{tabular}{lllll}
\hline Day & Positive premium & Negative premium & Modified positive premium & Standard premium (Private benefits) \\
\hline$t-2$ & $8.14 \%$ & $-3.13 \%$ & $17.43 \%$ & $5.23 \%$ \\
$t-1$ & $7.19 \%$ & $-3.02 \%$ & $15.82 \%$ & $4.74 \%$ \\
$t+1$ & $8.96 \%$ & $-3.08 \%$ & $18.57 \%$ & $5.57 \%$ \\
$t+2$ & $8.50 \%$ & $-3.03 \%$ & $17.80 \%$ & $5.34 \%$ \\
\hline
\end{tabular}

Note. Source: Our elaboration on Thomson Financial Data, Milano Finanza data, and Il Sole 24 Ore Data.

Table 3

Sample Description

\begin{tabular}{lccc}
\hline Variabile & \multicolumn{1}{c}{ Media } & Minimo & Massimo \\
\hline OWNERSHIP & 0.1547 & 0.0390 & 0.2999 \\
IDENTITY: COMPANY & 0.8182 & 0 & 1 \\
IDENTITY: INDIVIDUAL & 0.0909 & 0 & 1 \\
PYRAMID & 0.8182 & 0 & 1 \\
DUAL CLASS & 0.1818 & 0 & 1 \\
POWER OF CONTROL & 0.3990 & 0.0677 & 1 \\
SIZE* & 268,711 & 3,385 & $1,237,400$ \\
PERFORMANCE & -0.0005 & -0.0030 & 0.0014 \\
DEBT & 3.9506 & 1.1667 & 8.9478
\end{tabular}

Notes. ${ }^{*}$ amount in thousands. Source: Our elaboration based on Thomson Financial Data, Milano Finanza data, and Il Sole 24 Ore.

Table 4

Regression Analysis

\begin{tabular}{lcl}
\hline Variabile & Coefficient & $P$-value \\
\hline INTERCEPTS & 0.367018342 & 0.883262391 \\
SHAREHOLDING & -1.370521464 & 0.433875365 \\
IDENTITY: COMPANY & -0.257527005 & 0.194747571 \\
IDENTITY: INDIVIDUAL & 1.350658102 & 0.087402209 \\
POWER OF CONTROL & -0.415619946 & 0.409496803 \\
PYRAMIDS & 0.222177815 & 0.476648785 \\
DUAL CLASS & 0.046843632 & 0.893591197 \\
Ln(SIZE) & 0.010036082 & 0.943688054 \\
Ln(DEBT) & -0.176642133 & 0.219324523 \\
PERFORMANCE & -50.29010916 & 0.324937817 \\
\hline
\end{tabular}

Note. Source: Our elaboration based on Thomson Financial Data, Milano Finanza data, and Il Sole 24 Ore Data.

In order to achieve a model in which all variables are statistically significant, it proceeds with the selection of variables. In particular, the variables DUAL CLASS and LN(OWNERSHIP) do not reach statistical significance. With regard to the DUAL CLASS, its non-statistical significance is determined from the fact that the use of the dual 
class, as a mechanism to separate the ownership from the control, has decreased over the years. As regards, instead, the size of OWNERSHIP, the non-statistical significance is explained from the fact that the controlling shareholders are able to extract the private benefits even in small firms. The resulting model is the following.

Table 5

Model With Statistically Significant Variables

\begin{tabular}{lcl}
\hline Variabile & Coefficient & $P$-value \\
\hline INTERCEPTS & 0.535494872 & 0.004367193 \\
SHAREHOLDING & -1.136942382 & 0.020935661 \\
IDENTITY: COMPANY & -0.264661171 & 0.015446805 \\
IDENTITY: INDIVIDUAL & 1.234477723 & 0.000374941 \\
PYRAMIDS & 0.234624073 & 0.007983824 \\
POWER OF CONTROL & -0.528191051 & 0.013312632 \\
PERFORMANCE & -62.94775598 & 0.011952394 \\
Ln(DEBT) & -0.139554515 & 0.009785163 \\
\hline
\end{tabular}

Note. Source: Our elaboration based on Thomson Financial Data, Milano Finanza data, and Il Sole 24 Ore Data.

As the Table 5 shows, the $p$-value associated with each of the variables considered in the model is less than 0.05 , so we can deduce that there exists a statistically significant correlation between each variable and the premium.

In particular, the negative correlation with the size of ownership indicates that the premium, on average, decreases with the increasing participation. This is due to the fact that if a shareholder holds the absolute majority of the ordinary share, the premium associated with the remaining equity is negligible because the voting rights do not allow to influence the governance. In consequence, the probability of a competition for control is almost nil, as confirmed by the further negative relationship between the premium and the Shapley value. In addition, the negative relationship can be attributed to mechanisms that are often used, when the investment is reduced to separate ownership from control. In fact, if the shares capital held and therefore the cash flow rights are lower then the incentive to expropriate resources is greater.

The block premium is negatively correlated with the firm's performance, so the higher the performance is, the lower the block premium is. This can be explained as follows: the buyer may consider that under its control the company will be able to generate more profits and therefore is willing to buy the block to a higher premium. The negative correlation may also be due to the fact that firms with high private benefits are less profitable, or, conversely, to the fact that the presence of high profitability implies a low consumption of private benefits.

The negative correlation with debt can be justified by the behavior of the controlling shareholder, which tends to limit the debt like the other opportunistic actions when these can affect the value of the firm.

The identity of the buyer is a relevant variable for the size of the block premium and therefore the benefits. In particular, the block premium is on average higher when the buyer is an individual and is lower when is a firm. In fact, the individual's perception of private benefit is higher, especially as regards the non-pecuniary benefits, in terms of reputation and social prestige.

\section{Conclusions}

In literature, there is a broad recognition of the value of control rights because they represent the means by 
which a shareholder may obtain a control of a firm. In addition, researchers agree that this value depends largely on the ability to extract private benefits.

The empirical literature on international comparisons shows that the private benefits differ among countries. In particular, Italy in the past has been one of the countries with the highest high levels of private benefits.

The present study has confirmed what has been widely argued in the literature regarding the value that investors assign to the control. The empirical evidence, in fact, carried out on the sample, showed a positive differential between the price of the block and the market price on 68 percent of the cases analyzed.

Morevoer, the results fully confirm the theoretical predictions of this research. In fact, the premium of block shows a reduction compared with measures estimated from the previous researches on Italian listed companies. From 34.4 percent estimated for the period 1970-1991 (Caprio et al., 1994), the premium was down slightly to 27.4 percent in the period 1987-1992, had a further reduction to 21.8 percent in the period 1993-2003 (Massari et al., 2004), and so reaching to the estimation resulting from the present empirical work equal to 8 percent for the positive premium and equal to 17 percent for the modified premium.

Similarly, the private benefits standardized for the capital decrease from 12-14 percent in the period 1993-2004 to five percent resulting in this work. This confirms the theoretical assumption of the present study that the higher regulatory action for the minority shareholder protection occurred since the Consolidate Law has reduced significantly the size of benefits extracted by the controlling shareholders.

The regression of the block of premium on the explanatory variables typically used in the previous researches on private benefits, demonstrates that the results of this survey are comparable with those of the other analisys. In fact, the regression proves the statistical significance of the correlation between the resulting premium and the independent variables considered as determinants.

\section{References}

Barak, R., Cohen, S., \& Lauterbach, B. (2007). CEO pay in Israel and its relations to firm performance and ownership structure. Israeli Quarterly Journal of Economics, 54(2), 205-228.

Barclay, M. J., \& Holderness, C. G. (1989). Private benefits from control of public corporations. Journal of Financial Economics, 25, 371-395.

Barclay, M. J., \& Holderness, C. G. (1991). Negotied block trades and corporate control. Journal of Finance, 46, 861-878.

Barclay, M. J., \& Holderness, C. G. (1992). The law and large block trades. Journal of Law and Economics, 35, $265-294$.

Bebchuk, L. A. (1994). Efficient and inefficient sales of corporate control. Quarterly Journal of Economics, 109, $957-993$.

Bebchuk, L. A. (2005). The case for increasing shareholder power. Harvard Law Review, 118, 833-914.

Bennedsen, M., \& Wolfenzon, D. (2000). The balance of power in closely held corporations. Journal of Financial Economics, 58, 113-140.

Berglof, E., \& Perotti, E. (1994). Corporate governance structure of the Japanese financial keiretsu. Journal of Financial Economics, 36, 259-284.

Berle, A., \& Means, G. (1932). The modern corporation and private property. New York: Macmillan.

Caprio, L., Floreani, A., \& Radaelli, L. (1994). I trasferimenti del controllo di società quotate in Italia: un’analisi empirica dei prezzi e dei risultati per gli azionisti di minoranza. Finanza Imprese e Mercati, 3, 355-393.

Coates, J. C. (2003). Ownership, takeovers and EU Law: How contestable should EU corporations be? Law Working Paper, $11 / 2003$.

Coffee, J. C. (1991). Liquidity versus control: The institutional investor as corporate monitor. Columbia Law Review, 91, 1277-1368.

Demsetz, H. (1983). The structure of ownership and the theory of the firm. Journal of Law and Economics, 2, 375-390. 
Demsetz, H., \& Lehn, K. (1985). The structure of ownweship, causes and consequences. Journal of Political Economy, 6, 1155-1177.

Dyck, A., \& Zingales, L. (2004). Private benefits of control: An international comparison. Journal of Finance, 59, 537-600.

Ehrhardt, O., \& Nowak, E. (2003). Private benefits and minority shareholder expropriation (or what exactly are private benefits of control'), EFA 2003 Annual Conference Paper No. 809.

Enriques, L. (2000). The law on company directors' self-dealing: A comparative analysis. International and Comparative Corporate Law Journal, 2, 297-333.

Faccio, M., \& Lang, L. (2002). The ultimate ownership of Western European corporations. Journal of Financial Economics, 3, 365-395.

Fama, E. F., \& Jensen, M. C. (1983). Separation of ownership and control. Journal of Law and Economics, 26, 301-325.

Gilson, R. J., \& Gordon, J. N. (2003). Controlling shareholders. Columbia Law and Economics Working paper No. 228.

Gregoric, A., \& Vespro, C. (2009). Block trades and the benefits of control in Slovenia. The Economics of Transition, 17(1), $175-210$.

Grossman, S., \& Hart, O. (1988). One share-one vote and the market for corporate control. Journal of Financial Economics, 20, 175-202.

Hanouna, P., Sarin, A., \& Shapiro, A. C. (2001). Value of corporate control: Some international evidence. Working Paper, USC Marshall School of Business.

Harris, M., \& Raviv, A. (1988). Corporate control contests and capital structure. Journal of Financial Economics, 20 , 55-86.

Holderness, C. G. (2003). A survey of blockholders and corporate control. Economic Policy Review, 1, 51-64.

Jensen, C. M. (1986). Agency costs of free cash flow, corporate finance and takeovers. American Economic Review, 2, $323-329$.

Jensen, C. M., \& Meckling, W. (1976). Theory of the firm: Managerial behavior, agency costs and ownership structure. Journal of Financial Economics, 3, 305-360.

Johnson, S., La Porta, R., Lopez De Silanes, F., \& Shleifer, A. (2000). Tunelling. American Economic Review, 90, 22-27.

La Porta, R., Lopez De Silanes, F., \& Shleifer, A. (1999). Corporate ownership around the world. Journal of Finance, 2, $471-517$.

La Porta, R., Lopez De Silanes, F., Shleifer, A., \& Vishny, R. W. (1997). Legal determinants of external finance. Journal of Finance, 52, 1131-1150.

La Porta, R., Lopez De Silanes, F., Shleifer, A., \& Vishny, R. W. (1998). Law and finance. Journal of Political Economy, 106, 1113-1155.

Lease, R., McConnell, J. J., \& Mikkelsen, W. H. (1983). The market value of control in publicly- traded corporations. Journal of Financial Economics, 11, 439-471.

Levy, H. (1983). Economic evaluation of voting power of common stock. Journal of Finance, 38, 79-93.

Massari, M., Monge, V., \& Zanetti, L. ( 2004). Control premium in the presence of rules imposing mandatory tender offers: Can it be measured? IAFC, Università Bocconi.

Linciano, N. (2002). Non-voting shares and the value of control: The impact of corporate regulation in Italy. EFA 2003 Annual Conference Paper No. 400, EFMA 2003 Helinski Meetings.

Megginson, W. (1990). Restricted voting stock, acquisition premiums ,and the market value of corporate control. The Financial Review, 25, 175-198.

Mikkelson, W. H., \& Regassa, H. (1991). Premiums paid in block transactions. Managerial and Decision Economics, 12, $511-517$.

Modigliani, F., \& Perotti, E. (2000). Security versus bank finance: The importance of a proper enforcement of legal rules. FEEM, Working paper No. 37.

Morck, R., Shleifer, A., \& Vishny, R. W. (1989). Alternative mechanism for corporate control. The American Economic Review, 4, 842-852.

Morck, R., Wolfenzon, D., \& Yeung, B. (2005). Corporate governance, economic entrenchment and growth. Journal of Economic Literature, 43, 657-722.

Nicodano, G., \& Sembenelli, A. (2000). Private benefits, block transaction premia and ownership structure, Working Paper, University of Torino.

Nenova, T. (2003). The value of corporate votes and control benefits: A cross country analysis. Journal of Financial Economics, 68, 325-351.

Shapley, L. S., \& Shubik, M. ( 1954). A method for evaluating the distribution of power in a committee system. American Political Science Review, 48, 787-792.

Shleifer, A., \& Vishny, R. W. (1986). Large Shareholders and corporate control. The Journal of Political Economy, 3, 461-488. 
Shleifer, A., \& Vishny, R. W. (1997). A survey of corporate governance. The Journal of Finance, 2, 737-783.

Trojanowski, G. (2002). Equity block transfers in transition economies: Evidence from Poland. CEPR Discussion paper No. 3280. Venanzi, D. (2003). Struttura proprietaria, benefici privati del controllo e azioni di risparmio: il caso italiano. Finanza, Marketing e Produzione, 3, 45-82

Zingales, L. (1994). The value of voting right: A study of Milan stock exchange experience. Review of Financial Studies, 1, 125-148.

Zingales, L. (1995). What determines the value of corporate votes? Quarterly Journal of Economics, 110, 1047-1073. 